\title{
Effect of FK 506 on Spontaneous Diabetes in BB Rats
}

NORIKO MURASE, IRVING LIEBERMAN, MICHAEL A. NALESNIK, DANIEL H. MINTZ, SATORU TODO, ALLAN L. DRASH, AND THOMAS E. STARZL

From days 30-120 after birth, 59 BB rats were treated with water $(n=20)$ or FK 506 in intragastric doses of $1 \mathrm{mg} \cdot \mathbf{k g}^{-1} \cdot \mathrm{day}^{-1}(\mathbf{n}=19)$ or $2 \mathrm{mg} \cdot \mathrm{kg}^{-1} \cdot \mathrm{day}^{-1}(\mathrm{n}=$ 20). Diabetes developed in 75,15 , and $0 \%$ of the 3 groups, respectively. Animals protected from diabetes by FK $\mathbf{5 0 6}$ had normal intraperitoneal glucose tolerance tests, virtual absence histopathologically of autoimmune insulitis, and normal pancreatic insulin content. Forty-five to 75 days after stopping FK 506, $\sim 75 \%$ of the rats that were diabetes free at 120 days remained so. Diabetes 39:1584-86, 1990

T he demonstration that cyclosporin A (CsA) could prevent autoimmune BB rat diabetes (1-3) led to clinical trials with this drug in patients with recentonset insulin-dependent diabetes (4-6). Remissions were often accomplished if CsA was given soon enough and in adequate doses but at the cost of drug nephrotoxicity (4-6). FK 506, another potent immunosuppressive agent that is undergoing trials in transplantation (7), is chemically unrelated to CsA but also suppresses T-lymphocyte activation by inhibiting the transcription of mRNAs for earlyphase lymphokines, i.e., interleukin (IL) 2, IL-3, and interferon- $\gamma(8)$.

\section{RESEARCH DESIGN AND METHODS}

We examined the influence of daily enteral FK 506 given between ages 30 and 120 days on BB rat diabetes. We established the following experimental groups: group 1 ( $n=20)$ was given only tap water, group $2(n=19)$ was given $1 \mathrm{mg} \cdot \mathrm{kg}^{-1} \cdot \mathrm{day}^{-1} \mathrm{FK} 506$, and group $3(n=20)$ was given $2 \mathrm{mg} \cdot \mathrm{kg}^{-1} \cdot \mathrm{day}^{-1} \mathrm{FK} 506$. The FK 506 doses

From the Departments of Surgery, Pathology, Medicine, Neurobiology, and Pediatrics, University Health Center of Pittsburgh, University of Pittsburgh, Pennsylvania.

Address correspondence and reprint requests to Thomas E. Starzl, MD PhD, Department of Surgery, 3601 Fifth Avenue, Falk Clinic, Pittsburgh, PA 15213.

Received for publication 30 July 1990 and accepted in revised form 4 September 1990 . were extrapolated from earlier dose-efficacy studies and were estimated to be $1 / 4-1 / 8$ of those optimal for induction of long-lasting allograft acceptance (9). The 59 rats were obtained from seven consecutive litters, randomly deployed to the three sex-matched groups, raised under controlled lighting, and allowed tap water and regular rat food. Tap water or FK 506 was given by daily gastric intubation. FK 506 (Fujisawa, Osaka, Japan) was dispersed with hydroxypropyl methylcellulose and diluted in tap water by sonication. Onset of diabetes was diagnosed by glycosuria (tested 3 times/ wk) and confirmed by nonfasted blood glucose $>11.1 \mathrm{mM}$ from tail vein samples for 3 consecutive days.

\section{RESULTS}

During the 90-day treatment, diabetes developed in 75, 15.7 and $0 \%$ of tap water, low-dose FK 506, and high-dose FK 506 groups, respectively (Fig. 1). There was no mortality and very little inhibition (NS) of weight gain of the nondiabetic rats in the treatment groups (Fig. 2). The protective effect of FK 506 often outlasted the time of treatment (Table 1). Only five rats subsequently became diabetic ( 3 associated with pregnancy).

Glucose intolerance was not observed with the doses of FK 506 used in this study. In the nondiabetic control rats and the FK 506-protected rats, blood glucose levels obtained every 2 wk were normal (Fig. 3). Three rats from group 2 and 6 rats from group 3 had normal intraperitoneal glucose tolerance tests ( $2 \mathrm{~g}$ glucose $/ \mathrm{kg}$ body $\mathrm{wt}$ ) before they were killed for tissues on the last day of treatment (Fig. 4).

Other blood chemistry measurements and pancreatic insulin content were determined at the end of the FK 506 treatment in six of the nondiabetic survivors killed in group 2 and five of those killed in group 3 . There was no increase of blood urea nitrogen, creatinine, glutamic-oxaloacetic transaminase, or glutamic-pyruvic transaminase compared with six nondiabetic Wistar-Furth (non-BB) rats (Table 2). The livers and kidneys were normal histopathologically. At death, pancreatic tail tissue was diced into small pieces in cold acid-ethanol (75.2\% absolute ethanol, 1.4\% hydrochloric 


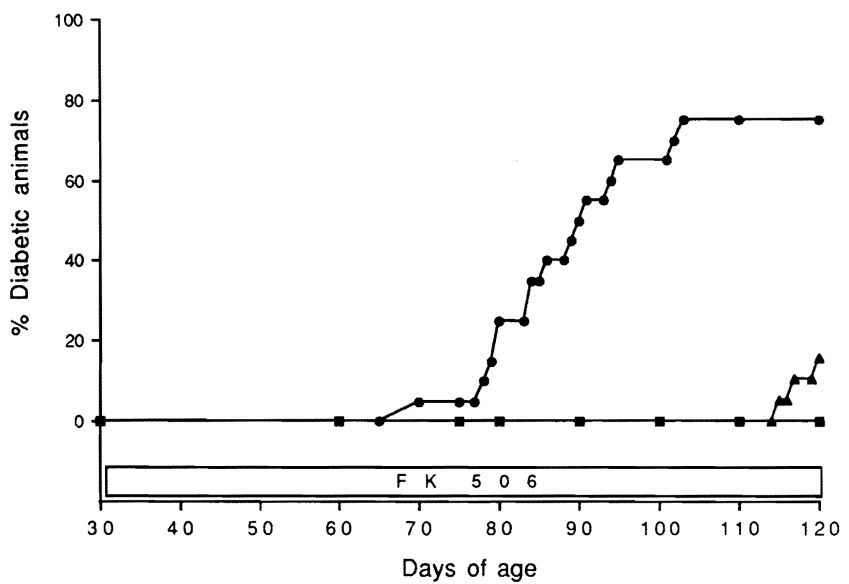

FIG. 1. Onset and incidence of diabetes under treatment with 1 $\mathrm{mg} \cdot \mathrm{kg}^{-1} \cdot$ day $^{-1}$ oral FK 506 ( $\Delta, 3$ of 19 developed diabetes), 2

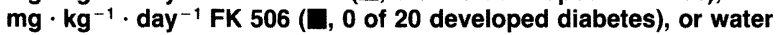
$(0,15$ of 20 developed diabetes) from 30 to 120 days of age.

acid, and $23.4 \%$ distilled $\mathrm{H}_{2} \mathrm{O}$ ) and sonicated vigorously for $10 \mathrm{~min}$ at $4^{\circ} \mathrm{C}$. After centrifugation at $500 \mathrm{rpm}$ for $10 \mathrm{~min}$, the supernatant fractions were frozen for subsequent assays of insulin by radioimmunoassay. Pancreatic insulin content in these rats was normal (Table 2). Histopathologically, these pancreases were free of the insulitis and periductular inflammation that was invariable in the untreated diabetic rats.

In additional analyses, immunocytochemical studies were performed on tissue sections from rats in groups 1-3 and four nondiabetic Wistar-Furth controls. Guinea pig anti-human insulin antibodies (Biogenex, San Ramon, CA) and rabbit anti-human glucagon antibodies (Amersham, Ayles-

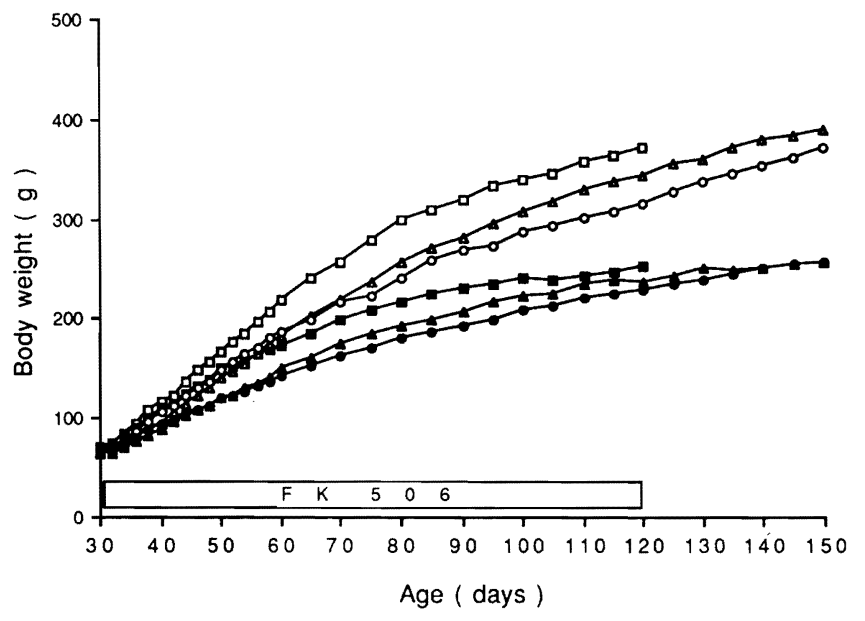

FIG. 2. Effect of FK 506 treatment on body weight in males $(\triangle, 1$ $\mathbf{m g} \cdot \mathbf{k g}^{-1} \cdot$ day $^{-1} ; \bigcirc, 2 \mathbf{~ m g} \cdot \mathbf{k g}^{-1} \cdot$ day $\left.^{-1}\right)$ and females $(\Lambda, 1 \mathrm{mg} \cdot$ $\mathrm{kg}^{-1} \cdot$ day $^{-1} ; \mathbf{O}, 2 \mathrm{mg} \cdot \mathrm{kg}^{-1} \cdot$ day $\left.^{-1}\right)$ compared with their male and female water-treated siblings ( $\square$ and $\square$, respectively). Only 5 watertreated rats were nondiabetic at 120 days.

bury, UK) have sufficient cross-reactivity with the respective rat hormones to allow immunohistochemical detection. Localization of these antibodies onto fixed paraffin-embedded tissues was visualized with the avidin-biotin procedure (Vector, Burlingame, CA). Color was developed with 3-amino9-ethylcarbazole (Biomeda, Foster City, CA). The entire procedure was performed on a computer-driven robot (Code-On, Fisher, Pittsburgh, PA), which allowed the placement of parallel control slides. In nondiabetic Wistar-Furth rats, insulin-containing cells were clearly demarcated and generally inhabited the centers of the islets. Glucagon-con-

TABLE 1

Fate after 120 days of rats treated with FK 506 from days $30-120$ of age

\begin{tabular}{lccc}
\hline & & FK 506 treated \\
\cline { 3 - 4 } & Control & $1 \mathrm{mg} \cdot \mathrm{kg}^{-1} \cdot$ day $^{-1}$ & $2 \mathrm{mg}^{-1} \mathrm{~kg}^{-1} \cdot \mathrm{day}^{-1}$ \\
\hline Survival $\geq 120$ days without diabetes & 5 of 20 & 16 of 19 & 20 of 20 \\
Killed at 120 days & 2 of 5 & 6 of 16 & 6 of 20 \\
Animals remaining $>120$ days & 3 & 10 & 14 \\
Survival $\geq 150$ days without diabetes & 3 & $8^{*}$ & 14 \\
Killed at 150 days & 3 of 3 & 2 of 8 & 2 of 14 \\
Animals remaining $>150$ days & & 6 & 12 \\
Survival 165-195 days without diabetes & & $9+$ \\
\hline
\end{tabular}

*Two other rats became diabetic at 132 and 147 days.

tThree other rats were used for breeding and became diabetic while pregnant at 170, 175, and 180 days.

TABLE 2

Blood chemistry and pancreatic insulin content at 120 days of age in 3 groups of rats

\begin{tabular}{lllcccc}
\hline Groups & \multicolumn{1}{c}{$\begin{array}{c}\text { BUN } \\
(\mathrm{mM})\end{array}$} & $\begin{array}{c}\text { Creatinine } \\
(\mu \mathrm{M})\end{array}$ & $\begin{array}{c}\text { GOT } \\
(\mathrm{U} / \mathrm{L})\end{array}$ & $\begin{array}{c}\text { GPT } \\
(\mathrm{U} / \mathrm{L})\end{array}$ & $\begin{array}{c}\text { Insulin content } \\
(\mathrm{pmol} / \mathrm{mg} \\
\mathrm{pancreas})\end{array}$ \\
\hline FK 506 & & & & & & \\
$1 \mathrm{mg} \cdot \mathrm{kg}^{-1} \cdot$ day $^{-1}$ & 6 & $8.6 \pm 2.5$ & $70.7 \pm 17.7$ & $130.3 \pm 93.0$ & $33.8 \pm 9.3$ & $32.4 \pm 21.0$ \\
$2 \mathrm{mg} \cdot \mathrm{kg}^{-1} \cdot$ day $^{-1}$ & 5 & $10.6 \pm 1.9$ & $88.4 \pm 35.4$ & $134.6 \pm 69.1$ & $35.0 \pm 9.4$ & $16.2 \pm 14.4$ \\
Control & 6 & $8.3 \pm 1.5$ & $70.7 \pm 8.8$ & $123.2 \pm 19.2$ & $36.3 \pm 2.9$ & $19.2 \pm 3.6$ \\
\hline
\end{tabular}

Values are means \pm SD. BUN, blood urea nitrogen; GOT, glutamic-oxaloacetic transaminase; GPT, glutamic-pyruvic transaminase. 


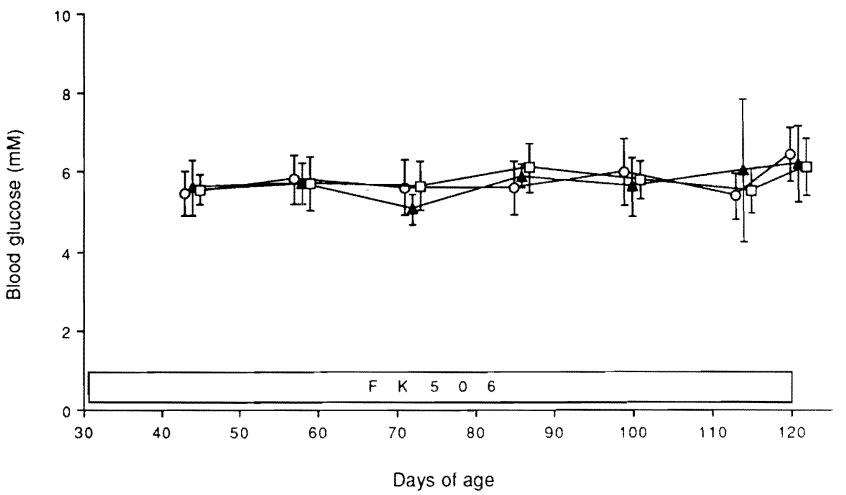

FIG. 3 Blood glucose levels at 30-120 days of age in nondiabetic survivors during FK 506 treatment $\left(O, 1 \mathrm{mg} \cdot \mathrm{kg}^{-1} \cdot\right.$ day $^{-1}, \mathbf{n}=16 ; \square$, $2 \mathrm{mg} \cdot \mathbf{k g}^{-1} \cdot$ day $\left.^{-1}, \mathbf{n}=20\right)$ compared with water treatment $(\Delta, n=5)$.

taining cells formed a distinct peripheral rim around the islets. With the development of diabetes in the untreated BB rats, insulin-containing cells disappeared completely, islet size was reduced, and the cells stained only with anti-glucagon antibodies. In contrast, normal-appearing distributions of insulin- and glucagon-containing cells were observed in 5 of 6 low-dose FK 506 and 3 of 3 high-dose FK 506 rats.

\section{DISCUSSION}

These data together with other observations support the notion that FK 506 may be a successful immune intervention agent for recent-onset diabetes. The therapeutic index of FK 506 in humans is better than CsA $(7,10)$, even though it is expected to have a qualitatively similar toxicity profile, including diabetogenic, neurotoxic, and nephrotoxic potential. Although the drugs are chemically unrelated, the central action of both is speculated to be inhibition of the enzyme peptidylprolyl isomerase (PPlase), which is the principal constituent of their cytosolic binding sites. The ubiquitous distribution of PPlase, including kidney and pancreas, implies that drugs that modulate it will affect multiple nonimmunologic metabolic processes (11). However, evidence is mounting that these consequences will not vitiate the value of FK 506 in transplantation or for the treatment of autoimmune diseases $(7,10,11)$.

\section{ACKNOWLEDGMENTS}

This study was supported by research grants from the Veterans Administration, Project Grant DK-29961 from the Na-

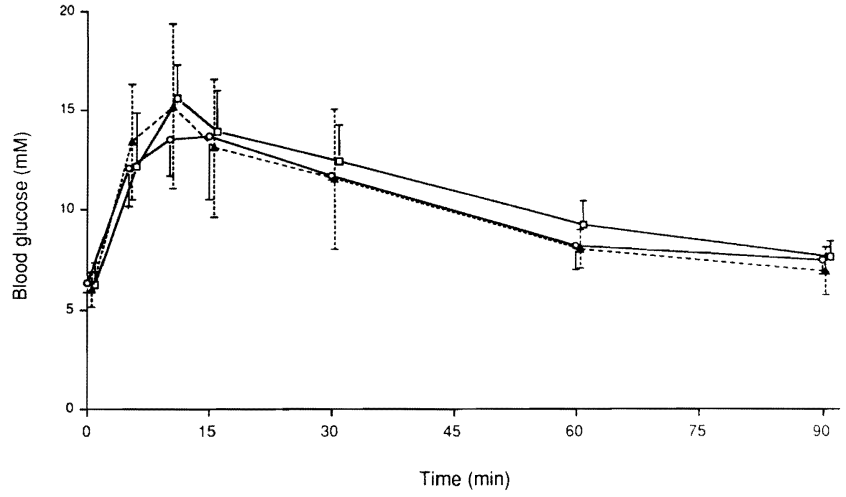

FIG. 4. Blood glucose levels during intraperitoneal glucose tolerance test before death on day 120 in BB rats treated with oral FK $506(0,1$ $\mathrm{mg} \cdot \mathbf{k g}^{-1} \cdot$ day $^{-1}, \mathbf{n}=3 ; \square, 2 \mathrm{mg} \cdot \mathbf{k g}^{-1} \cdot$ day $^{-1}, \mathbf{n}=6$ ) compared with nondiabetic Wistar-Furth (non-BB) rats $(\Delta, n=3)$. Glucose $(2 \mathrm{~g} / \mathrm{kg})$ was administered at 0 min.

tional Institutes of Health, and the Renziehausen Grant of the Children's Hospital of Pittsburgh.

\section{REFERENCES}

1. Laupacis A, Stiller CR, Gardell C, Keown P, Dupre J, Wallace AC: Cyclosporin prevents diabetes in BB Wistar rats. Lancet 1:10-12, 1983

2. Like $A A$, Dirodi V, Thomas S, Guberski DL, Rossini AA: Prevention of diabetes mellitus in the BB/W rat with cyclosporin-A. Am J Pathol 117:9297, 1984

3. Brayman KL, Armstrong BA, Shaw LM, Rosaro TG, Tomaszewski JE, Barker CF, Naji A: Prevention of diabetes in BB rats by intermittent administration of cyclosporine. Surgery 102:235-41, 1987

4. Stiller CR, Dupre J, Gent M, Jenner MR, Keown PA, Laupacis A, Martell R, Rodger NW, Graffenried BV. Wolfe BM: Effects of cyclosporine immunosuppression in insulin-dependent diabetes mellitus of recent onset. Science 223:1362-67, 1984

5. Assan R, Feutren G, Debray-Sachs M, Quiniou-Debrie MC, Laborie C, Thomas G, Chatenoud L, Bach JF: Metabolic and immunological effects of cyclosporin in recently diagnosed type I diabetes mellitus. Lancet 1:6771,1985

6. Stiller CR, Dupre J: Immune interventional studies in type I diabetes: summary of the London (Canada) and Canadian-European experience. In Immunotherapy of Diabetes and Selected Autoimmune Diseases. Eisenbarth GS, Ed. Boca Raton, FL, CRC, 1989, p. 73-84

7. Starzl TE, Todo S, Fung J, Demetris AJ, Venkataramanan R, Jain A: FK 506 for human liver, kidney and pancreas transplantation. Lancet 2:10001004,1989

8. Kino T, Hatanaka H, Miyata S, Inamura N, Nishiyama M, Yajima T, Goto T. Okahara M, Kohsaka M, Aoki N, Ochiai T: FK-506, a novel immunosuppressant isolated from a streptomyces. II. Immunosuppressive effect of FK 506 in vitro. J Antibiotics 40:1256-65, 1987

9. Murase N, Todo S, Lee PH, Lai H, Chapman F, Nalesnik MA, Makowka L, Starz| TE: Heterotopic heart transplantation in the rat under FK 506 alone or with cyclosporine. Transplant Proc 19 (Suppl. 6):71-75, 1987

10. Todo S, Fung JJ, Starzl TE, Tzakis A, Demetris AJ, Kormos R, Jain A, Alessiani M, Takaya S: Liver, kidney, and thoracic organ transplantation under FK 506. Ann Surg 212:295-305, 1990

11. Starzl TE, Fung JJ, Todo S: Contempo 90: transplantation. JAMA 263:2686-87, 1990 